original densities 3 days after treatment (from a mean of approximately 18 aphids to $\leq 0.1$ aphid per leaf). Thus, the aphids showed much greater susceptibility to organophosphates in August 1988 at the end of the growing season than during July 1987. These field trial results prompted laboratory studies to determine whether pesticide resistance was a factor in the variable level of pesticide efficacy achieved in controlling cotton aphid.

\section{Screening for resistance}

Cotton aphids were collected during 1988 and 1989 from cotton fields located throughout the valley. Early season collections were made in June or July and aphids were reared on cotton in the greenhouse. In September, late-season cotton aphids were collected from these same sites and reared separately. Wingless adults from each of aphid colony were tested with the following five insecticides: three organophosphates (Metasystox- $R$ 2EC, 100 ppm oxydemeton-methyl; Lorsban 4EC, 316 ppm chlorpyrifos; and Bidrin 8EC, 100 ppm dicrotophos), one pyrethroid (Capture 2EC, 10 ppm bifenthrin), and one chlorinated hydrocarbon (Thiodan 3EC, 316 ppm endosulfan) (table 3). The concentrations chosen for testing were high enough to cause more than $80 \%$ mortality of susceptible aphid populations.

Table 3 shows the percentage of cotton fields with aphids resistant to each of the five pesticides during the 1988 and 1989 surveys. If we examine the first column (June/July 1988) we see that 23 to $46 \%$ of the 13 cotton fields surveyed had aphids that were resistant to one or more of the organophosphates, suggesting that organophosphate resistance is a problem in valley cotton aphids.

The fact that populations resistant to one organophosphate tended to be resistant to other organophosphates suggests that cross-resistance exists within this chemical group. In contrast, only $15 \%$ of the sites tested in the laboratory had Thiodan-resistant aphids and no site had aphids resistant to the pyrethroid Capture. As Capture has only recently become fully registered for pest control in cotton, we would not expect the cotton aphid's resistance to it. Based on these surveys, Thiodan should continue to effectively control cotton aphid in some growing areas.

The percentages of early season (June/ July) cotton fields with organophosphateresistant aphids increased between 1988 and 1989 from 46,23 , and $38 \%$ to 86,43 , and $71 \%$ for Metasystox-R, Lorsban, and Bidrin, respectively. Thus, the organophosphate resistance problem in the San Joaquin Valley cotton aphid apparently worsened (table 3). The percentage of sites with Thiodan- and Capture-resistant cotton aphids did not appear to change between 1988 and 1989.

In both 1988 and 1989, the percentage of cotton fields with resistant cotton aphids (table 3 ) and the level of resistance in those aphids (fig. 1) was highest in the early season surveys (June and July) and lowest in the late-season surveys (Septem- ber) for all pesticides tested. This means that organophosphates, as well as other pesticides, should be more effective against late-season aphid populations than early season aphid populations, which is the result observed in field tests.

We do not know why the aphid loses some of its resistance as the season ends. However, resistance may decrease because of changes in the aphid's physical shape,

\begin{tabular}{|c|c|c|c|c|c|}
\hline \multirow[b]{2}{*}{ Insecticide } & \multirow{2}{*}{$\begin{array}{c}\text { Class of } \\
\text { insecticide }\end{array}$} & \multirow[b]{2}{*}{ Rate } & \multicolumn{3}{|c|}{$\begin{array}{l}\text { Percentage of pretreatment } \\
\text { aphids remaining } \\
\text { (mean aphids per leaf) } \\
\text { Days after treatment }\end{array}$} \\
\hline & & & -1 & 1 & 5 \\
\hline & & Ib a.i./ac & & & \\
\hline Check & & & $100(20.3)$ & $102(16.8)$ & $100(22.6)$ \\
\hline Pyrethrins (Pyrenone) & pyrethrin & 0.5 & $100(46.7)$ & $88(27.8)$ & $28^{\star}(9.4)$ \\
\hline \multicolumn{6}{|l|}{$\begin{array}{l}\text { Oxydemeton-methyl + } \\
\text { pyrethrins }\end{array}$} \\
\hline $\begin{array}{l}\text { (Metasystox-R + } \\
\text { Pyrenone) }\end{array}$ & $\begin{array}{l}\text { organophosphate } \\
\text { + pyrethrin }\end{array}$ & $0.5+0.5$ & $100(39.6)$ & $43(18.5)$ & $17^{*}(8.9)$ \\
\hline Dicrotophos (Bidrin) & organophosphate & 0.5 & $100(25.2)$ & $86(21.6)$ & $106(32.1)$ \\
\hline Dimethoate (Cygon) & organophosphate & 0.5 & $100(56.3)$ & $88(50.3)$ & 40 (18.6) \\
\hline \multicolumn{6}{|l|}{ Oxydemeton-methyl } \\
\hline (Metasystox-R) & organophosphate & 0.5 & $100(85.9)$ & $79(42.7)$ & $32^{*}(22.6)$ \\
\hline Endosulfan (Thiodan) & $\begin{array}{l}\text { chlorinated } \\
\text { hydrocarbon }\end{array}$ & 0.5 & $100(24.4)$ & $174(34.2)$ & $80(19.0)$ \\
\hline
\end{tabular}

"Mean significantly different from check by ANOVA/LSD $(P<0.03)$.

TABLE 2. Percentage of pretreatment aphid densities, Aphis gossypii, remaining for each pesticide treatment in a field trial conducted in Shafter, California, August 19, 1988

\begin{tabular}{|c|c|c|c|c|}
\hline \multirow[b]{2}{*}{ Insecticide } & \multirow{2}{*}{$\begin{array}{c}\text { Class of } \\
\text { insecticide }\end{array}$} & \multirow[b]{2}{*}{ Rate } & \multicolumn{2}{|c|}{$\begin{array}{l}\text { Percentage of pretreatment } \\
\text { aphids remaining } \\
\text { (mean aphids per leaf) } \\
\text { Days after treatment }\end{array}$} \\
\hline & & & -1 & 3 \\
\hline & & Ib a.i./ac & & \\
\hline Check & & & $100(18.6)$ & $95(17.8)$ \\
\hline Dimethoate (Cygon) & organophosphate & 0.5 & $100(19.9)$ & $<1\left(0.1^{*}\right)$ \\
\hline Chlorpyrifos (Lorsban) & organophosphate & 1.0 & $100(20.1)$ & $<1\left(<0.1^{*}\right)$ \\
\hline Naled (Dibrom) & organophosphate & 1.0 & $100(18.6)$ & $1\left(0.1^{*}\right)$ \\
\hline \multicolumn{5}{|l|}{ Oxydemeton-methyl } \\
\hline (Metasystox-R) & organophosphate & 0.5 & $100(19.6)$ & $<1\left(<0.1^{*}\right)$ \\
\hline Profenofos (Curacron) & organophosphate & 0.5 & $100(17.1)$ & $<1\left(<0.1^{*}\right)$ \\
\hline
\end{tabular}

"Mean significantly different from check by ANOVA/LSD $(P<0.05)$.

Table 3. Percentage of cotton fields with pesticide-resistant cotton aphids Percentage of fields with resistant cotton aphids

\begin{tabular}{|c|c|c|c|c|c|}
\hline \multirow[b]{2}{*}{ Insecticide } & \multirow[b]{2}{*}{$\begin{array}{c}\text { Critical } \\
\text { concentration }\end{array}$} & \multicolumn{2}{|c|}{1988} & \multicolumn{2}{|c|}{1989} \\
\hline & & $\begin{array}{l}\text { Jun/Jul } \\
(n=13) \dagger\end{array}$ & $\begin{array}{c}\text { Sep } \\
(n=13)\end{array}$ & $\begin{array}{c}\text { July } \\
(n=14)\end{array}$ & $\begin{array}{c}\text { Sep } \\
(n=20)\end{array}$ \\
\hline & ppm & \multicolumn{4}{|c|}{ 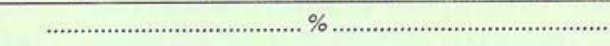 } \\
\hline \multicolumn{6}{|l|}{ Organophosphates: } \\
\hline $\begin{array}{l}\text { Metasystox-R } 2 E C \\
\text { (oxydemeton-methyl) }\end{array}$ & 100 & 46 & 31 & 86 & 75 \\
\hline $\begin{array}{l}\text { Lorsban 4EC } \\
\text { (chlorpyrifos) }\end{array}$ & 316 & 23 & 15 & 43 & 15 \\
\hline $\begin{array}{l}\text { Bidrin 8EC } \\
\text { (dicrotophos) }\end{array}$ & 100 & 38 & 23 & 71 & 55 \\
\hline $\begin{array}{l}\text { Chlorinated hydrocarbon } \\
\text { Thiodan } 3 E C \\
\text { (endosulfan) }\end{array}$ & 316 & 15 & 0 & 7 & 0 \\
\hline $\begin{array}{l}\text { Pyrethroid: } \\
\text { Capture 2EC } \\
\text { (bifenthrin) }\end{array}$ & 10 & 0 & 0 & 0 & 0 \\
\hline
\end{tabular}



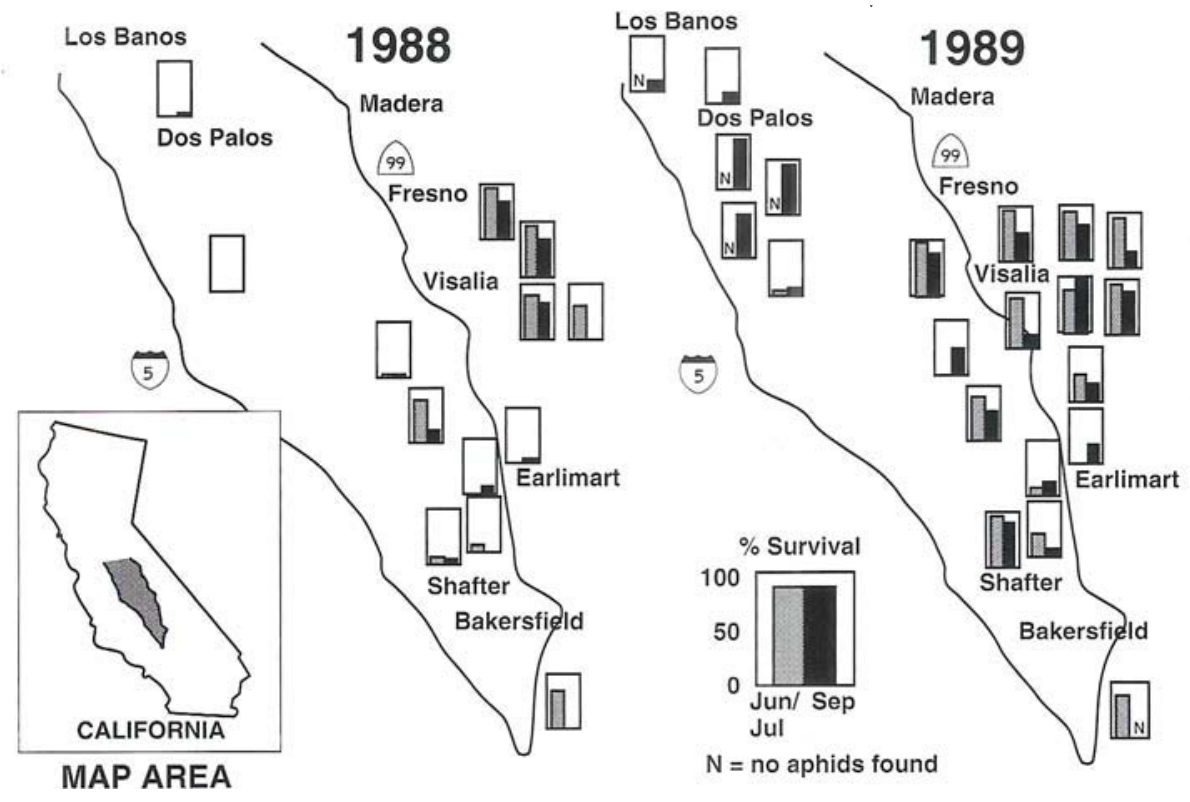

Fig. 1. Percentages of cotton aphids that survived organophosphate pesticide (Metasystox-R) treatments at various San Joaquin Valley locations in 1988 and 1989. Survival was checked in June and July (gray bar) and in September (solid bar) of each year. The greater the survival rate, the greater the resistance to Metasystox-R.

in the enzymes inside the aphid, or in the nutrition of the aphid's host plant. Although the percentage of cotton fields with resistant aphids decreased as the season progressed, there were still many fields with organophosphate-resistant aphids at the end of the season. Thus, we cannot assume that resistance will always disappear at the end of the season.

\section{Location of resistant aphids}

The majority of the highly resistant aphid sites were located on the valley's east side, in Tulare County (fig. 1), where aphids appear earliest in the season. We observed that cotton fields with aphid problems were planted early and initially had few natural enemies. Apparently, the aphids multiply quickly when there is little control by such natural enemies as parasitic wasps, lacewings and ladybeetles. Because there is no economic threshold for early season cotton aphid damage, growers become concerned and resort to broad-spectrum pesticides. This action prevents buildup of the few available natural enemies. Growers are then forced to continue to apply pesticides each time the residual effects wear off and the aphid population again begins to build. Thus, four to six early season pesticide sprays are applied. Natural enemies are susceptible to broad-spectrum pesticides, so it is difficult for them to survive these frequent sprayings. On the San Joaquin Valley's west side (fig. 1), late-season cotton aphid resistance in cotton was associated with neighboring melon fields where pesticides were applied in July and August to reduce aphid populations.

Because Tulare County had the greatest number of sites with early season cotton aphid resistance in 1988 and 1989 (fig. 1), weekly surveys for aphids on weeds, cotton, citrus and other crops were made from March 26 through May 8, 1990 and on September 25, 1990. Figure 2 illustrates the average survival of the aphids on Metasystox- $R$ after collection from various host plants during each of these months. The cotton aphid appeared first in March and April on many weed hosts, such as little mallow, common groundsel, fiddleneck, redroot pigweed, and mustard.

Cotton aphid was also found in one citrus orchard in April. The cotton aphid appeared in cotton approximately the first week of May. During May, cotton aphids were found on such weeds as little mal-

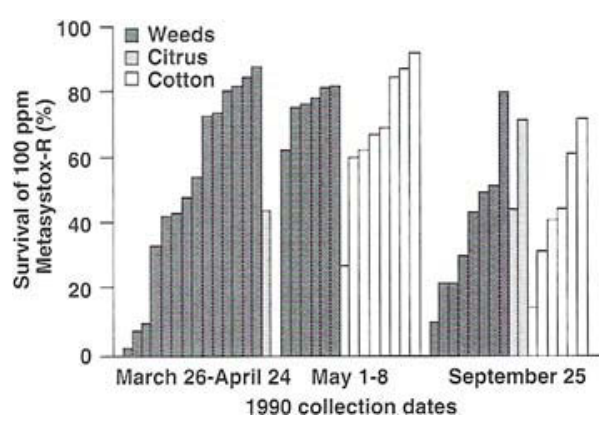

Fig. 2. Percentage survival of Tulare County cotton aphids treated with Metasystox-R. Aphids were collected from weeds (dark gray bar), citrus (light gray bar), and cotton (white bar) three times during 1990 . low, mare's tail, and curly dock as well as cotton. Data in figure 2 show that many cotton aphid populations in Tulare County had resistance to organophosphates ( $>20 \%$ survival on 100 ppm Metasystox-R) before they migrated to emerging cotton. Thus, the cotton aphid lives on many host plants, including a variety of weeds, and many populations have resistance to organophosphates before they are treated with pesticides in cotton fields.

In September, cotton aphids were abundant on cotton and were also found on such weeds as little mallow, horseweed, flax-leaved fleabane, prostrate pigweed, and redroot pigweed. Figure 2 shows that organophosphate resistance declined from an average of $70 \%$ survival in May to $40 \%$ survival in September, despite the fact that pesticide applications are made on cotton between May and September.

Aphids were collected from three citrus orchards and generally showed high tolerance for Metasystox-R. Organophosphates are frequently used in citrus to control lepidopterous larvae, thrips, and armored scale during April through September. Pesticide applications to that crop would further select cotton aphid for pesticide resistance.

\section{Managing resistance}

Although most San Joaquin Valley cotton growers do not spray broad-spectrum pesticides more than once during a single growing season, organophosphates, carbamates, and chlorinated hydrocarbons have been used for over 20 years to control thrips, aphid, lygus, whitefly, worms, and spider mites on cotton. These same pesticides are used in other crops, such as citrus and melons, that may be sources of cotton aphid. Thus, although the selection pressure within fields is relatively low, resistance may finally be developing because of the long time these pesticides have been used.

It is clearly evident from our research that organophosphate resistance has developed in the cotton aphid in the San Joaquin Valley. The next question to be addressed is: How to manage it? The main approach to take is to avoid use of organophosphate pesticides and to emphasize nonchemical controls. Early season pesticide sprays are the least effective in controlling cotton aphid and are most disruptive of natural enemies. We do not yet have an economic threshold for aphid damage in early season cotton; however, generally, parasitoids and predators can control these aphids if broad-spectrum pesticide sprays are completely avoided.

Early season cotton aphids are the least threatening to cotton quality. Therefore, the best strategy would be to avoid all 
early season broad-spectrum pesticide sprays. When pesticides are necessary, attempts should be made to use pesticides other than organophosphates. This may be difficult, because most pesticides registered to control cotton aphid are organophosphates. The chlorinated hydrocarbon Thiodan appears to be effective in most locations and the pyrethroid Capture is effective and now fully registered. Capture, however, is toxic to natural enemies and removal of beneficials frequently leads to secondary outbreaks of pests. If growers avoid broad-spectrum pesticide use in the early season, pesticides will be more effective later when sticky cotton is a problem.

Although pesticides other than organophosphates may effectively control organophosphate-resistant aphids, their use should also be limited to slow the development of resistance. Populations of cotton aphid in Mississippi have been shown to be highly resistant to organophosphates (Lorsban, Metasystox-R, and Bidrin), carbamates (Temik), chlorinated hydrocarbons (Thiodan), and pyrethroids (Capture). The cotton aphid has resistance to all of these chemical classes in Mississippi because all of these pesticides have been used for many years or many times during the season to control such key pests as bollworm and boll weevil.

Research is underway to establish economic thresholds for aphid damage on California cotton so that growers can more accurately assess the need for pesticides. In addition, research is being initiated to determine which parasitoids and predators are most useful for controlling cotton aphid. When we know which natural enemies are most effective, we can then find ways to increase their numbers in areas where cotton aphid numbers are consistently damaging.

E. E. Grafton-Cardwell is an Extension IPM Specialist and Assistant Research Entomologist in the Department of Entomology, UC Riverside, and is stationed at the UC Kearney Agricultural Center; T. F. Leigh is an Entomologist in the Department of Entomology, UC Davis; W. J. Bentley is an Entomology Farm Advisor for Kern County, and P. B. Goodell is an area IPM Specialist for the South Central California Region, Cooperative Extension.

The authors thank Jeffrey Granett and the Department of Entomology at UC Davis for use of a laboratory to conduct this research; John DeBenedictis, Lijie Jia, Yuling Ouyang, and Stacy Vehrs for technical assistance; and Dow Chemical, Mobay, Dupont, and FMC corporations for providing insecticides. This project was supported in part by funds from the Cotton Pest Control Board and the Western Regional Pesticide Impact Assessment Program.

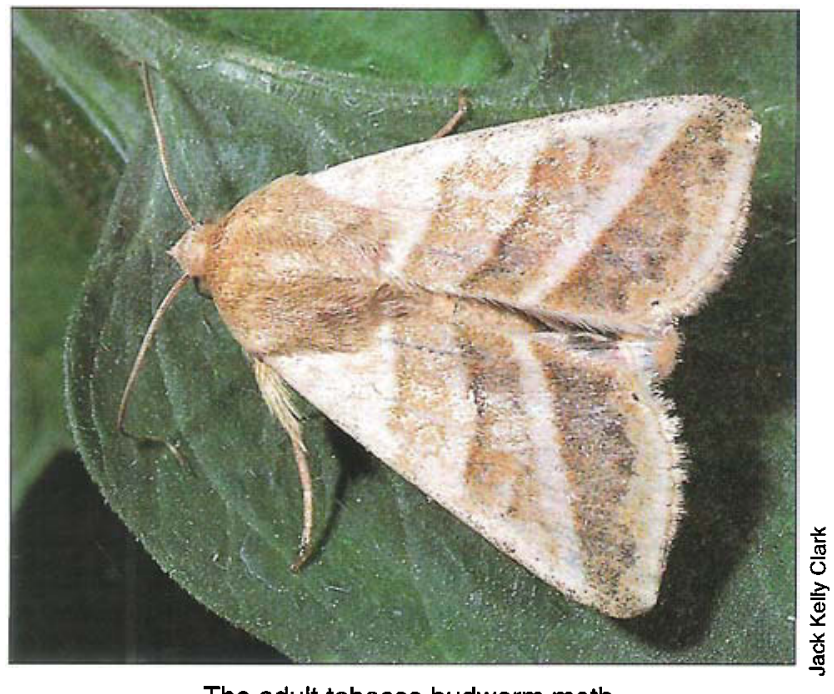

The adult tobacco budworm moth.

\title{
Tobacco budworm, pest of petunias, can be managed with Bt
}

\author{
Nita A. Davidson $\square$ Marvin G. Kinsey $\square \quad$ Lester E. Ehler \\ Gordon W. Frankie
}

Damage to petunias by tobacco budworm has reduced the popularity of this colorful summer annual in some parts of California. However, properly timed applications of Bacillus thuringiensis $(B t)$ can effectively manage budworm in home gardens and in greenhouses. Lacewing applications proved ineffective on petunias, but may control tobacco budworm on other plants.

Although petunias produce abundant summer color, their popularity among home gardeners, landscape professionals, and the nursery industry in and around Sacramento has declined lately because of increasing damage caused by the tobacco budworm, Heliothis virescens (F.). In the Sacramento area, home gardening is widespread, and petunias have until recent times been among the most popular flowers planted. They have also been planted extensively in commercial landscapes such as shopping centers.

Tobacco budworm is a New World species recorded on more than 100 hostplant species including tobacco, cotton, tomato, sunflower, and soybean. Budworm larvae feed principally on reproductive structures (i.e., buds) and growing points. Tobacco budworm was first observed attacking cotton in Southern California in the early 1970s; however, it had been recorded much earlier on ornamentals, such as petunia, geranium, and snapdragon.

In the Sacramento area, budworm moths deposit their eggs on flower buds of geranium in late spring to early summer. Once hatched, the early instars burrow inside the buds; later instars feed primarily on the floral parts, particularly the mature flowers. High densities of larvae of any stage can devour all buds and flowers.

On petunia, the moth usually deposits her eggs on the leaves, and larvae feed on flower buds and opened flowers. Once they have eaten the flowers on a plant, the larvae readily feed on developing seed pods and leaves. The frass occurring on budworm-infested geraniums and petunias is considered unattractive by many home gardeners, as are the late instars crawling or feeding on plants. Although budworms can cause considerable damage to geraniums, they can devastate petunias because the plants are often small and are usually planted as annuals; geraniums, on the other hand, are long-lived perennials that can tolerate budworm feeding pressure from year to year.

We studied the tobacco budworm's impact on petunias in home gardens and in greenhouses (1) to characterize feeding 